\title{
Zastosowanie metod dendrochronologicznych w badaniach lawin śnieżnych
}

\author{
The dendrochronological methods of snow avalanche investigation
}

\author{
Ryszard J. Kaczka1', Karolina Janecka1, Michał Lempa', Zofia Rączkowska² \\ ${ }^{1}$ Wydział Nauk o Ziemi, Uniwersytet Śląski, Sosnowiec; e-mail: ryszard.kaczka@us.edu.pl \\ ${ }^{2}$ Instytut Geografii i Przestrzennego Zagospodarowania, Polska Akademia Nauk, Kraków
}

Zarys treści: Lawiny śnieżne pomimo swojej siły pozostawiają niejednorodny zapis w środowisku. Z tego powodu rekonstrukcja momentu wystąpienia i wielkości lawiny jest zadaniem trudnym. Jednym z pośrednich dowodów ich aktywności są miejsca, gdzie lawiny docierają do lasu pozostawiając swój ślad w skali makro (obniżanie górnej granicy lasu) i mikro (uszkodzenia pojedynczych drzew). Odpowiednio zaadaptowane metody dendrochronologiczne pozwalają datować zdarzenia lawinowe. W wyniku połączenia analiz dendrochronologicznych z innymi metodami badawczymi uzyskujemy wielowymiarowy obraz aktywności lawin w przeszłości. Zastosowanie podstawowych technik dendrochronologicznych do datowania zdarzeń lawinowych zostało omówione na przykładzie wyników badań w Białym Żlebie w Tatrach Wysokich. Opracowana dla tego miejsca rekonstrukcja aktywności lawin obejmuje ponad 100 lat i wskazuje na pięć dużych zdarzeń lawinowych w okresie od 1912 do 2009 roku. Włączenie do analiz technik GIS umożliwiło rozszerzenie rekonstrukcji o elementy przestrzenne, informujące o zasięgu przeszłych zdarzeń.

Słowa kluczowe: lawiny śnieżne, dendrochronologia, rekonstrukcja, GIS, Tatry

\begin{abstract}
Despite their strength, snow avalanches leave a very diverse record in the environment. For this reason, the reconstruction of the occurrence, time and magnitude of avalanches is a really demanding task. It can only be performed in places where avalanches reach forests, leaving their marks in the macroscale (lowering the upper timberline) and microscale (damaging individual trees). Appropriately adapted dendrochronological methods allow dating the avalanche events. Combining the dendrochronological analyses with other techniques enables to obtain a multi-dimensional image of avalanche events. The application of the basic dendrogeomorphological techniques is discussed on the example of the results of the research from the Biały Żleb chute located in the High Tatras. The obtained reconstruction of avalanche activity covers more than 100 years and points to five major avalanche events in the period from 1912 to 2009 . The employment of GIS techniques allowed to extend the reconstruction by a spatial element indicating the range of the past events.
\end{abstract}

Key words: snow avalanche, dendrochronology, reconstruction, GIS, the Tatras

\section{Wstęp}

Lawiny śnieżne występują we wszystkich górach, gdzie w strefie krioniwalnej opady zapewniają powstawanie pokrywy śnieżnej o miąższości przekraczającej $0,5 \mathrm{~m}$ na stokach o nachyleniu $15^{\circ}$ (Kotarba, Starkel 1972, Bajkiewicz-Grabowska, Mikulski 2011) lub $30^{\circ}$ (Schweizer i in. 2003). W Tatrach, wszystkie stoki o nachyleniu powyżej $30^{\circ}$ uznawane są za sprzyjające powstawaniu lawin (Chomicz, Knazovicky 1974). Lawiny śnieżne definiowane
\end{abstract}

są jako proces gwałtownego przemieszczania się mas śniegu po stoku na skutek zakłócenia spójności oraz napięcia między kolejnymi warstwami śniegu a napięciem hamującym (Kłapa 1959). Chociaż lawiny śnieżne nie są traktowane jako proces geomorfologiczny, to ze względu na powodowane skutki stanowią obiekt zainteresowania geomorfologów (m.in. Rapp 1960, Luckman 1978, Becht 1995, Jomelli, Francou 2000, Hreško i in. 2005, Owen i in. 2006, Rączkowska i in. 2015). Mogą one stanowić poważne niebezpieczeństwo dla zdrowia i życia ludzi, 
infrastruktury i mienia oraz wprowadzać wyraźne zmiany w środowisku przyrodniczym gór wysokich. Do najważniejszych zaliczyć można zmiany przebiegu górnej granicy lasu (Myczkowski 1956, 1962, Czajka i in. 2012, Kaczka i in. 2015). Lawiny wyraźnie obniżają lokalny jej przebieg, zakłócając związek maksymalnego pionowego zasięgu gatunków leśnych z warunkami klimatycznymi. $\mathrm{Z}$ tego powodu, wobec współczesnych zmian zagospodarowania terenu i ocieplania się klimatu, są zaliczane do głównych czynników ograniczających podnoszenie się górnej granicy lasu. W środkowej Europie lawiny występują we wszystkich górach, od Szumawy po Czarnohorę, gdzie funkcjonuje naturalna górna granica lasu. Charakterystyczną cechą zdarzeń lawinowych w naszej części Europy jest stwarzanie przez nie zagrożenia głównie dla turystów oraz infrastruktury związanej ze sportami zimowymi. W górach takich jak np. Alpy, lawiny stanowią poważne zagrożenie również dla wysoko położonych miejscowości. Pomimo wielowiekowej obecności człowieka w Sudetach i Tatrach, brak jest systematycznych obserwacji lawin, a co za tym idzie wiedzy o ich historii, intensywności i tendencjach występowania. Nie oznacza to jednak, że zjawisko, pozostające na styku zainteresowań niwologii ${ }^{1}$, klimatologii i geomorfologii, nie było dotychczas obserwowane i badane. W Polsce już od początku $\mathrm{XX}$ wieku powstawały naukowe doniesienia na temat lawin (Zaruski 1910, 1911, Smoleński 1932). Większość obserwacji i badań koncentrowała się na obszarze Tatr, gdzie częstotliwość ich występowania jest największa. Głównym źródłem informacji o zdarzeniach lawinowych są kroniki Górskiego Ochotniczego Pogotowia Ratunkowego (GOPR) i Tatrzańskiego Ochotniczego Pogotowia Ratunkowego (TOPR) oraz dla krótkiego okresu czasu systematyczne obserwacje i pomiary na Stacji badawczej Instytutu Geografii i Przestrzennego Zagospodarowania Polskiej Akademii Nauk na Hali Gąsienicowej (Kłapa 1959, Chomicz, Kłapowa 1969, Kłapowa 1974, 1976). Podobnie dla Babiej Góry, Sudetów, jak i Bieszczad wszelkiego rodzaju informacje $i$ dane o lawinach mają charakter wyrywkowy. Należy pamiętać, że sytuacja ta jest typowa nie tylko dla polskiej części Sudetów i Karpat, lecz ogólnie dla gór Środkowej Europy. Określenie czasowych trendów występowania i wielkości zdarzeń lawinowych ma kluczowe znaczenie dla prowadzenia odpowiedniej polityki zapobiegania stratom i zarządzania tego typu geozagrożeniami.

Rekonstrukcja częstości występowania i przestrzennego zasięgu lawin jest zadaniem trudnym ze względu na cechy materiału stanowiącego lawinę (śnieg) oraz ślady jakie pozostawia w środowisku sam proces. Jedynie lawiny gruntowe, powodując erozję w strefie zrywu i/lub transportu oraz depozycję w strefie końcowej, zapisują się w rzeźbie terenu (Klimaszewski 1981). Zejście nawet bardzo dużej lawiny pyłowej nie pozostawia po sobie śla-

\footnotetext{
Nazwa używana przez Instytut Meteorologii i Gospodarki Wodnej - Państwowy Instytut Badawczy (IMGW), gdzie istnieje Sekcja Niwologii DSPO IMGW zajmująca się m.in. opracowywaniem cotygodniowego biuletynu śniegowego.
}

dów geomorfologicznych i zaledwie po kilku tygodniach obserwator może mieć trudności z odnalezieniem materialnych śladów aktywności lawinowej. Wyjątek stanowią lawiny, które docierają do górnej granicy lasu. Niezależnie od tego, czy są to lawiny gruntowe czy pyłowe, wyrządzają szkody w drzewostanie, pozostawiając ślady w mikroskali (uszkodzenia pojedynczych drzew) i w makroskali (zmiany przebiegu granicy lasu).

Celem niniejszego opracowania jest przedstawienie podstawowych zastosowań dendrochronologii w rekonstrukcji zdarzeń lawinowych obejmujących swoim zasięgiem piętra leśne. Charakterystyka kolejnych technik badawczych ilustrowana jest konkretnymi wynikami badań z Białego Żlebu w Tatrach Wysokich.

\section{Dendrochronologia i dendrogeomorfologia}

Dendrochronologia to metoda badawcza opierająca się o analizy corocznie wytwarzanych w zdrewniałych częściach roślin przyrostów (Schweingruber 1989, 1996, Zielski, Krąpiec 2009). Najczęściej wykorzystywana jest w strefach klimatycznych gwarantujących wyraźną, fenologicznie uwarunkowaną produkcję przyrostów rocznych drewna wtórnego. Dzięki niepowtarzalności cech fizycznych i chemicznych słojów możliwe jest określenie daty wykształcenia każdego przyrostu z dokładnością do jednego roku kalendarzowego. Do głównych cech fizycznych słojów zalicza się: szerokość przyrostu rocznego oraz gęstość drewna, a do cech chemicznych: zawartość różnych pierwiastków i związków w drewnie, w tym kompozycję izotopów stabilnych w celulozie. Przyrosty roczne większości gatunków drzew składają się z dwóch porcji ksylemu o odmiennych cechach i wyglądzie - drewna wczesnego i drewna późnego (Fritts 1976, Zielski, Krąpiec 2009). Dla przykładu, w warunkach klimatu chłodnego drewno wczesne powstaje w okresie od maja do sierpnia, natomiast późne, w drugiej części sezonu wegetacyjnego tj. od sierpnia do początku października (Rossi i in. 2006, 2007). W niektórych przypadkach może być to wykorzystane do uzyskania większej precyzji i rozdzielczości czasowej datowania z dokładnością np. do tygodnia (Kaczka $\mathrm{i}$ in. 2010). W klasycznej dendrochronologii datowanie polega na określeniu momentu powstania każdego, szczególnie ostatniego (podkorowego) przyrostu rocznego drzewa (Douglass 1941).

Współcześnie techniki datowań dendrochronologicznych służą określeniu nie tylko momentu ścięcia drzewa lub jego naturalnej śmierci, ale także czasu powstania różnych zakłóceń w jego wzroście promieniowym. Procesy geomorfologiczne, tj. obrywy skalne, spływy gruzowe, czy osuwiska mogą powodować uszkodzenia pnia lub korony drzewa (Carrara 1979, Bollschweiler i in. 2008a, Butler i in. 2010, Stoffel, Bollschweiler 2008). Podobne odziaływanie obserwuje się w przypadku lawin śnieżnych (Corona i in. 2010, Luckman 2010). Czas wystąpienia tego typu zjawisk może zostać określony 
w oparciu o analizy zakłóceń w sekwencji szerokości przyrostów rocznych, jak również zmian anatomicznych drewna (Potter 1969, Decaulne, Sæmundsson 2008, Lundström i in. 2008, Pelfini, Santilli 2008, Stoffel i in. 2010). Z tego powodu badanie go na poziomie komórkowym znajduje tutaj swoje zastosowanie (Potter 1969, Carrara 1979, Stoffel i in. 2006, Decaulne, Sæmundsson 2008, Butler i in. 2010, Corona i in. 2010, Luckman 2010). Zespół technik dendrochronologicznych stosowanych w badaniach geomorfologicznych określany jest mianem dendrogeomorfologii. Nazwę tę na początku lat siedemdziesiątych XX wieku wprowadził Alestalo (1971). Wykorzystywane w dendrogeomorfologii założenia metodyczne są tożsame z tymi stosowanymi w dendrochronologii i muszą być przestrzegane na każdym etapie prac badawczych (Alestalo 1971, Schweingruber 1989, 1996).

\section{Teren badań}

Przedstawione w opracowaniu przykłady zastosowań technik dendrochronologicznych pochodzą z badań przeprowadzonych w Białym Żlebie w Dolinie Rybiego Potoku w Tatrach Wysokich (ryc. 1). Dolina Rybiego Potoku to żłób polodowcowy, w obrębie którego występują piętra geoekologiczne, od leśnego w jej dnie do seminiwalnego w pobliżu grani (Kotarba $\mathrm{i}$ in. 1987). Zbocza charakteryzują się dużą ilością żlebów, w których powszechnie występują lawiny śnieżne. Wzdłuż doliny prowadzi jeden z najbardziej popularnych szlaków turystycznych Polski - droga Oswalda Baltzera, odwiedzany rocznie przez ponad 600000 osób (TPN 1999-2013). W kilku miejscach jest on przecinany przez duże szlaki lawinowe, między innymi przez Biały Żleb (Kłapa 1959). $\mathrm{Z}$ tego powodu lawiny stanowią potencjalne zagrożenie dla turystów odwiedzających tą część Tatr, mimo iż analizy historycznych i współczesnych materiałów kartograficznych wskazują, że aktywność lawinowa zmniejsza się (Kaczka i in. 2015).

\section{Glówne etapy prac}

\section{Prace kameralne - przygotowanie do badań terenowych}

Specyfiką badań dendrochronologicznych jest konieczność zgromadzenia odpowiedniej wiedzy na temat badanego procesu i charakterystyki samego nośnika informacji, tj. lasu i występujących lokalnie gatunków drzew. Studia kameralne muszą dotyczyć pozyskania informacji o historii aktywności lawinowej, charakteru rzeźby i klimatu terenu badań. Głównymi źródłami są publikacje naukowe, klasyczne i elektroniczne mapy tematyczne oraz rejestry lawinowe prowadzone przez odpowiednie instytucje (GOPR, TOPR, IMGW, parki narodowe, służby leśne, ośrodki naukowe). Uzyskane informacje umożliwiają określenie nie tylko cech terenu w jakim planowane są badania, ale również czasowego i przestrzennego zasięgu oddziaływania lawin. Dla przykładu, analiza współczesnych i historycznych map oraz zdjęć lotniczych pozwoliła ocenić, że w Tatrach większość szlaków lawinowych sięgających górnej granicy lasu w czasie ostatniego półwiecza uległa częściowemu lub całkowitemu zarośnięciu (Czajka i in. 2012, Kaczka i in. 2015). Natomiast, na Babiej Górze w podobnym okresie czasu, lokalny przebieg górnej granicy lasu wzdłuż szlaków lawinowych nie zmienił się. Wskazuje to na stały udział lawin w kontrolowaniu jej przebiegu (Czajka i in. 2015). Podobna sytuacja ma miejsce w Białym Żlebie w Tatrach Wysokich, gdzie górna granica lasu została, w stosunku do przebiegu klimatycznego, obniżona o ponad $300 \mathrm{~m}$, ale od 1938 roku pozostaje stabilna (Lempa $\mathrm{i}$ in. 2014) (ryc. 2).

Analizy kartograficzne dostępnych źródeł (zdjęć lotniczych, wielkoskalowych map topograficznych) pozwalają wyznaczyć granice planowanych prac terenowych. Badania dendrochronologiczne koncentrują się głównie w wąskim pasie, na granicy szlaku lawinowego i lasu, będącego pod wpływem współczesnych lawin. Jednakże w miarę oddalania się od niej możliwe jest uzyskanie star-

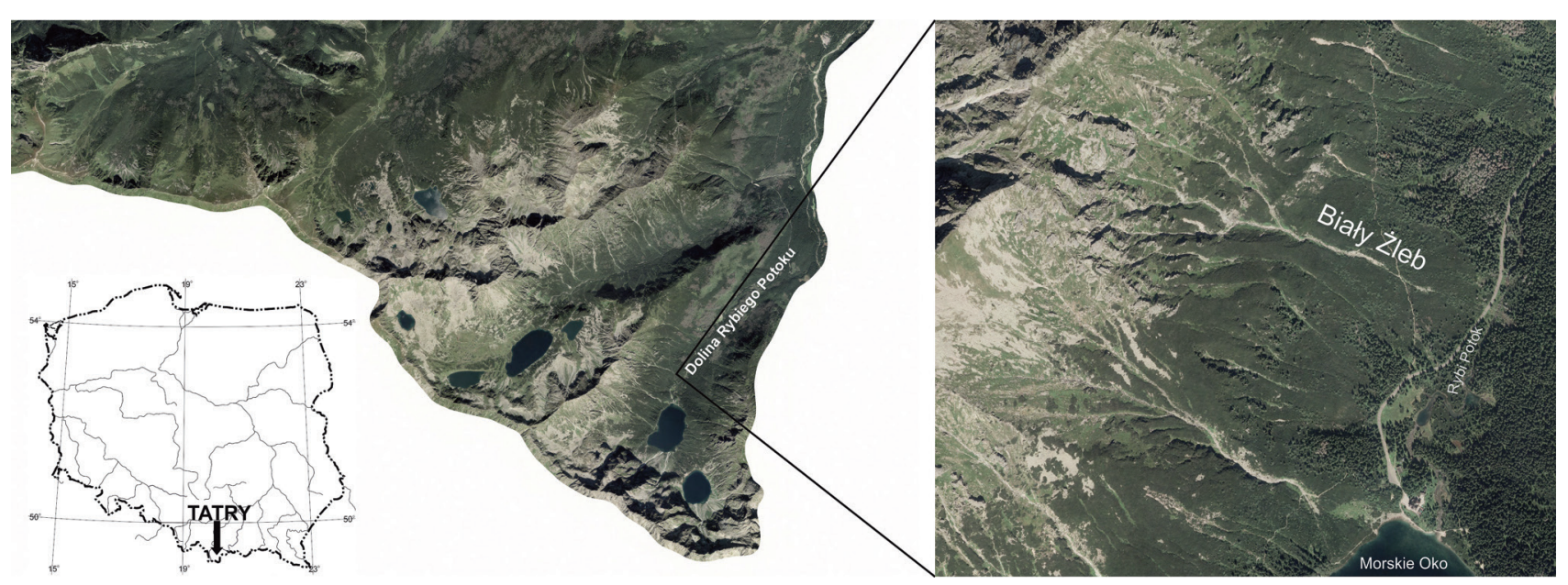

Ryc. 1. Lokalizacja terenu badań, Biały Żleb w Tatrach Wysokich

Fig. 1. The location of the study site, Biały Żleb chute in the High Tatras 


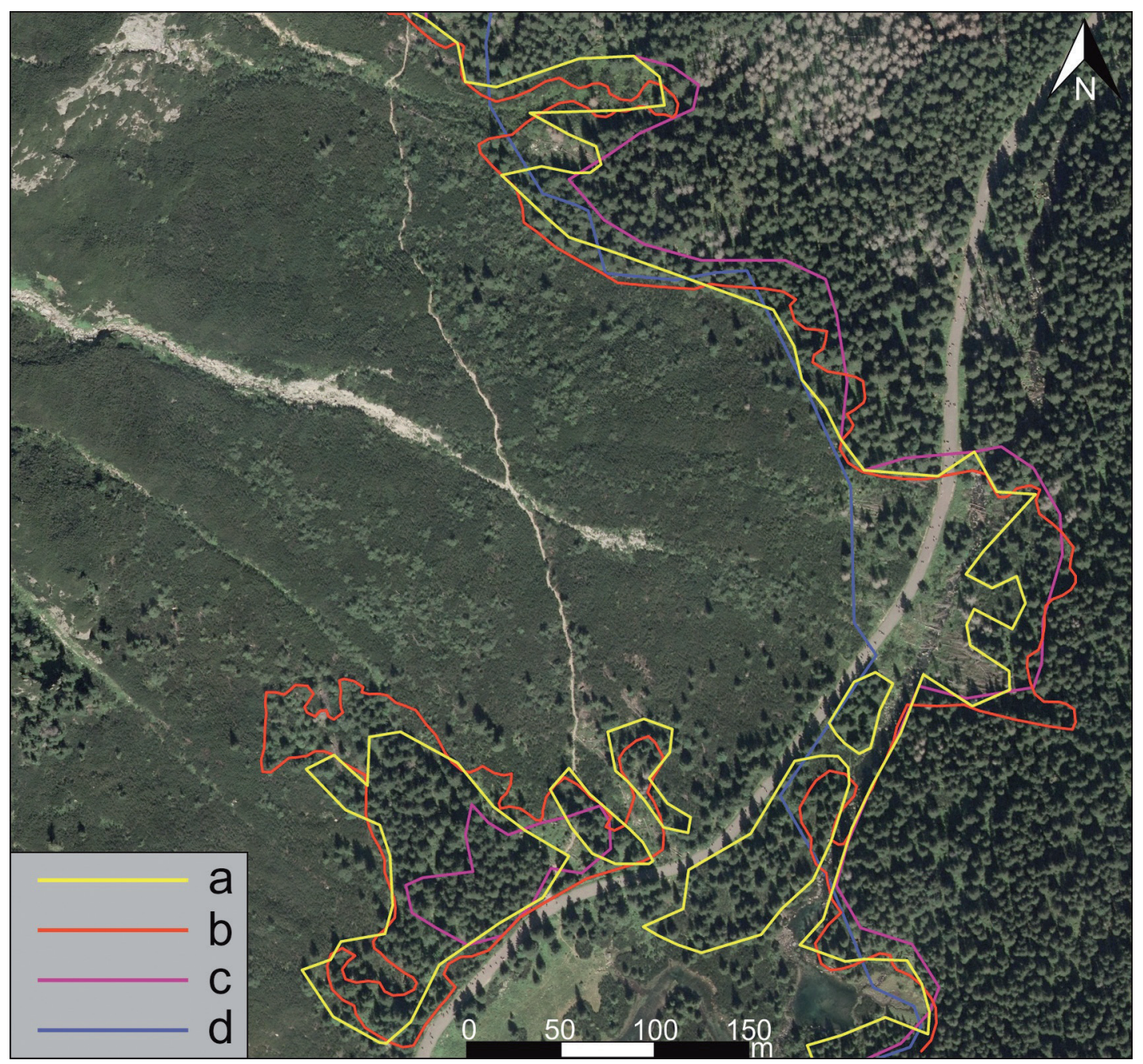

Ryc. 2. Zmiany przebiegu górnej granicy lasu w Białym Żlebie w okresie 1938-2009 wyznaczone na podstawie analiz zdjęć lotniczych z lat 2012 (a), 1977 (b) 1955 (c) i historycznej mapy topograficznej z roku 1938 (d)

Fig. 2. Changes of the timberline course in area of the Biały Żleb chute during the period of 1938-2012 based on aerialphotos for the following years 2012 (a), 1977 (b), 1955 (c) and historical topographic map for 1938 (d)

szego materiału dendrochronologicznego, będącego zapisem starszych zdarzeń lawinowych (Stoffel i in. 2013, Stoffel, Corona 2014).

\section{Prace terenowe - selekcja drzew, pobór prób dendrochronologicznych, dodatkowe pomiary}

Dendrochronologiczne badania lawin polegają na określeniu czasu wystapienia kolejnych zdarzeń lawinowych. Do tego celu wykorzystywane są drzewa, które w trakcie zejścia lawiny doznały uszkodzenia pnia lub ich wzrost został zaburzony na skutek dekapitacji. Głównym narzędziem stosowanym do poboru prób dendrochronologicznych pozostaje skonstruowany w ok. 1855 roku świder przyrostowy Presslera (Pressler 1866, Grisino-Mayer 2003). Pozwala on na pobieranie $z$ drzew prób w kształcie rdzenia o średnicy od 4,35 mm, poprzez najczęściej stosowane $5,15 \mathrm{~mm}$, do $12 \mathrm{~mm}$. Wykorzystanie świdrów o średnicy 5,15 mm umożliwia uzyskanie porcji drewna wystarczającej do przeprowadzenia większości pomiarów przy minimalnym uszkodzeniu drzewa. Powstałe otwory szybko zabliźniają się bez szkody dla drzewa. Pozyskane próby wymagają odpowiedniego przechowywania, gwarantującego dostarczenie do laboratorium bez ich uszkodzenia. Dendrogeomorfologiczną specyfiką poboru prób jest konieczność odpowiedniego wytypowania drzewa z widocznym uszkodzeniem pnia lub korony (Stoffel, Bollschweiler 2008) oraz dokonanie jego pomiarów, tj. obwód drzewa, długość i szerokość blizny, wysokość blizny nad powierzchnią ziemi lub wysokość, na której doszło do dekapitacji. Te informacje w połączeniu $\mathrm{z}$ danymi dendrochronologicznymi pozwolą na uzyskanie dodatkowych wiadomości o zdarzeniu lawinowym. Jedną z najważniejszych informacji jest ustalenie np. za pomocą pomiarów GPS położenia każdego z opróbowanych drzew w stosunku do szlaku lawinowego.

Transportowany przez lawiny śnieg, rumosz drzewny i skalny, uderzając w drzewo, może doprowadzić do uszkodzenia pni i gałęzi. Podczas gdy analizy uszkodzeń gałęzi są bardzo problematyczne, uszkodzenia pni stanowią najczęściej stosowany w badaniach dendrogeomorfologicznych nośnik informacji. W przypadku odpowiednio dużej siły uderzenia zniszczeniu ulega kora i występujące pod nią dwie miękkie i niezwykle istotne 

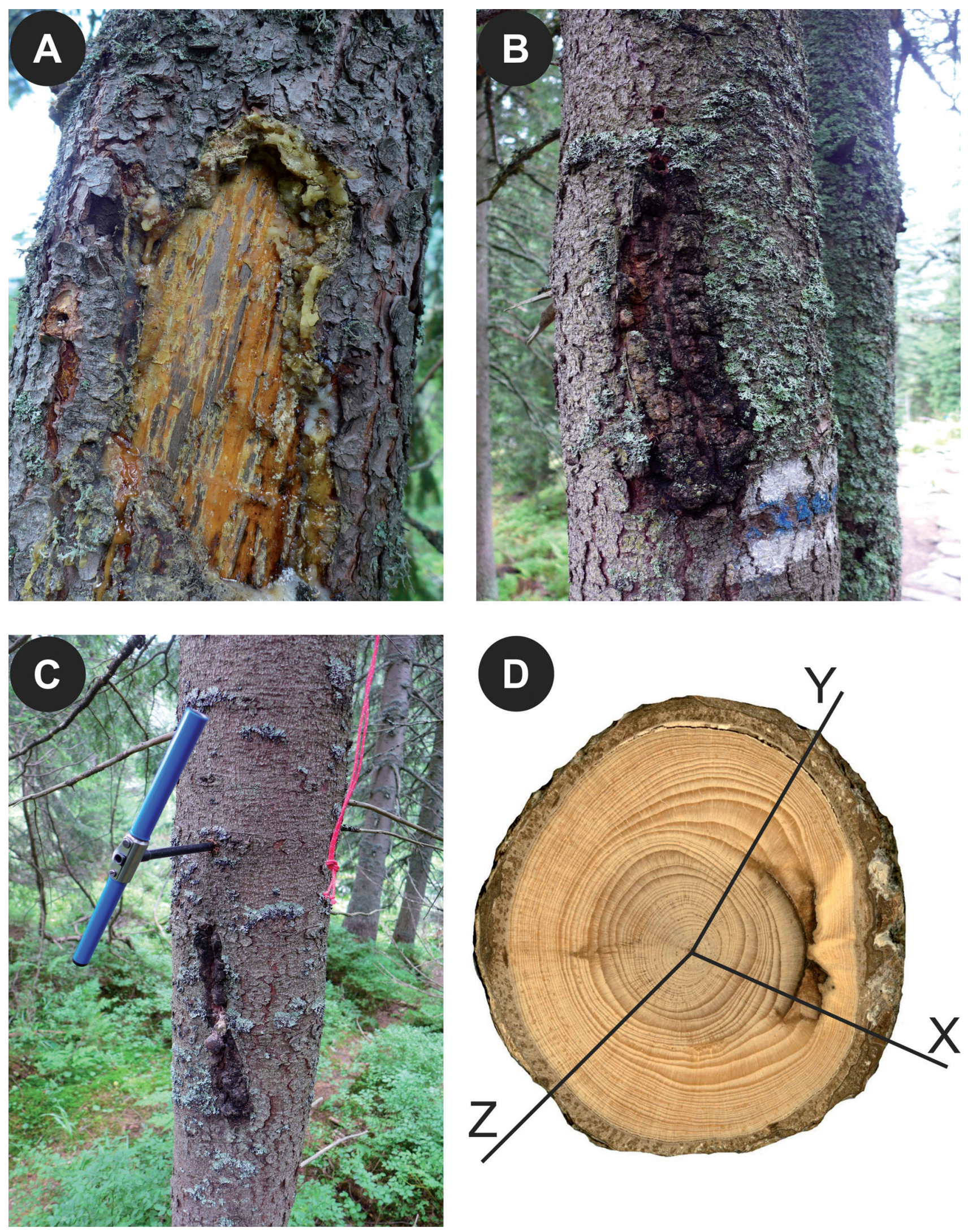

Ryc. 3. Rodzaje blizn powstałych po uszkodzeniu drzew (świerk pospolity) przez lawiny

A - blizna otwarta, B - blizna zamknięta. Miejsca poboru prób z blizny (D): próba X - bezpośrednio z blizny; odwiert Y - nad blizną (C), pozyskiwany w celu analizy traumatycznych kanałów żywicznych, próba $Z$ - nieuszkodzonej części pnia

Fig. 3. The sort of scars caused by injury induced by snow avalanche on Norway spruce

A - open scar, B - closed scar. The strategy of sampling (D): X sample, directly from the scar, Y sample with traumatic resin ducts obtained directly above the injury $(\mathrm{C}), \mathrm{Z}$ sample from undisturbed section of the tree trunk 
dla funkcjonowania drzewa tkanki: łyko (floem) i miazga twórcza (kambium waskularne). Jedną z głównych funkcji drugiej z nich jest produkcja komórek drewna wtórnego, czyli słojów rocznych. Komórki kambium nie mają zdolności regeneracyjnych i ich uszkodzenie powoduje trwałe zahamowanie powstawania przyrostów w danej części pnia. W przypadku gatunków iglastych powstała rana jest przez drzewo doraźnie zabezpieczana żywicą transportowaną licznymi kanałami żywicznymi o dużej średnicy (traumatyczne kanały żywiczne - TKZ). Zabliźnianie uszkodzenia polega na wytworzeniu tkanki kalusowej (Schweingruber 1993, Zielski, Krąpiec 2009) oraz zmianie charakteru wzrostu części kolejnych przyrostów rocznych. W obrębie samego uszkodzenia nie powstają już słoje, natomiast te, wytwarzane dookoła niego wykazują nie tylko przyrost pierścieniowy, ale i boczny. Dzięki temu odsłonięte drewno wtórne jest powoli zakrywane, a uszkodzenie przybiera charakter częściowo (ryc. 3a) lub całkowicie zasklepionej blizny (ryc. 3b). Powstające w nieuszkodzonej części pnia przyrosty roczne nie charakteryzują żadne zmiany związane $\mathrm{z}$ tym procesem. W celu określenia momentu uszkodzenia pnia pobierane są odwierty w 3 miejscach (ryc. $3 \mathrm{~d}$ ): bezpośrednio z miejsca zranienia (X) (ryc. 3d), powyżej lub obok miejsca uszkodzenia - drewno z traumatycznymi kanałami żywicznymi (Y) (ryc. 3c i ryc. 3d) oraz z nieuszkodzonej części pnia - pozyskanie kompletnej, niezaburzonej sekwencji przyrostów (Z) (ryc. 3d). Istotnymi czynnościami na tym etapie prac terenowych jest dokładne oznakowanie prób oraz wykonanie odpowiedniej dokumentacji (patrz powyżej), stanowiącej istotny element analiz przeprowadzanych w laboratorium.

Energia kinetyczna mas śniegu oraz towarzysząca lawinie fala uderzeniowa powodują również uszkodzenia korony drzewa. Często występującym rodzajem takiego uszkodzenia jest złamanie całej górnej części korony i utrata głównego stożka wzrostu - dekapitacja (Buttler, Malanson 1985, Stoffel i in. 2010). W przypadku mniej- szych drzew jest to spowodowane bezpośrednim naporem samego śniegu. Większe drzewa w zetknięciu z falą uderzeniową lub frontem lawiny wpadają w drgania, które sinusoidalnie zwiększają swoją amplitudę w górę pnia (tzw. zjawisko „hula-hop”, Stoffel i in. 2005, Dorren, Berger 2006, Lundström i in. 2009). W efekcie dziesięciocentymetrowe odchylenie od pionu u podstawy drzewa może zostać przetransformowane w kilkumetrowe odchylenie przy wierzchołku, co w efekcie prowadzi do złamania górnej części korony. Utrata wierzchołka wzrostu i części aparatu fotosyntetycznego znacznie pogarsza kondycję drzewa. Dla wzrostu promieniowego skutki dekapitacji, która miała miejsce w zimie, widoczne są w następnym sezonie wegetacyjnym. Powstały po zdarzeniu lawinowym przyrost jest wyraźnie węższy od poprzednich, a taka redukcja utrzymuje się w kilku kolejnych latach (Buttler, Malanson 1985, Stoffel i in. 2010). Stopniowa odbudowa zniszczonej korony i wytworzenie nowego wierzchołka wzrostu powodują poprawę kondycji drzewa. W rezultacie, po kilku, kilkunastu wąskich przyrostach rocznych zaczynają odkładać się słoje o szerokościach zbliżonych do tych sprzed dekapitacji. Drzewo, które uległo dekapitacji można rozpoznać w oparciu o jego charakterystyczny pokrój, szczególnie kształt pnia i korony oraz rozgałęzienie (ryc. 4). Metoda ta jest zalecana jedynie w przypadku drzew iglastych, które z natury charakteryzują się prostym pniem i symetryczną koroną (wzrost monopodialny). Pobór prób z drzew, których korona została uszkodzona, jest zbliżony do standardowej, należy jednak pamiętać o pozyskaniu rdzenia poniżej związanego z dekapitacją zniekształcenia pnia.

Ruch masy śniegu, fala uderzeniowa i późniejszy statyczny napór w obrębie lawiniska mogą doprowadzić do powstania jeszcze innych zmian wzrostu. Drzewa wywrócone lub mocno pochylone mogą wypuszczać pionowe odrosty, które z czasem przejmują rolę głównego pędu (Laska, Kaczka 2010). Pochylone drzewa, aby odzyskać pionowe ustawienie pnia, produkują drewno reakcyjne,

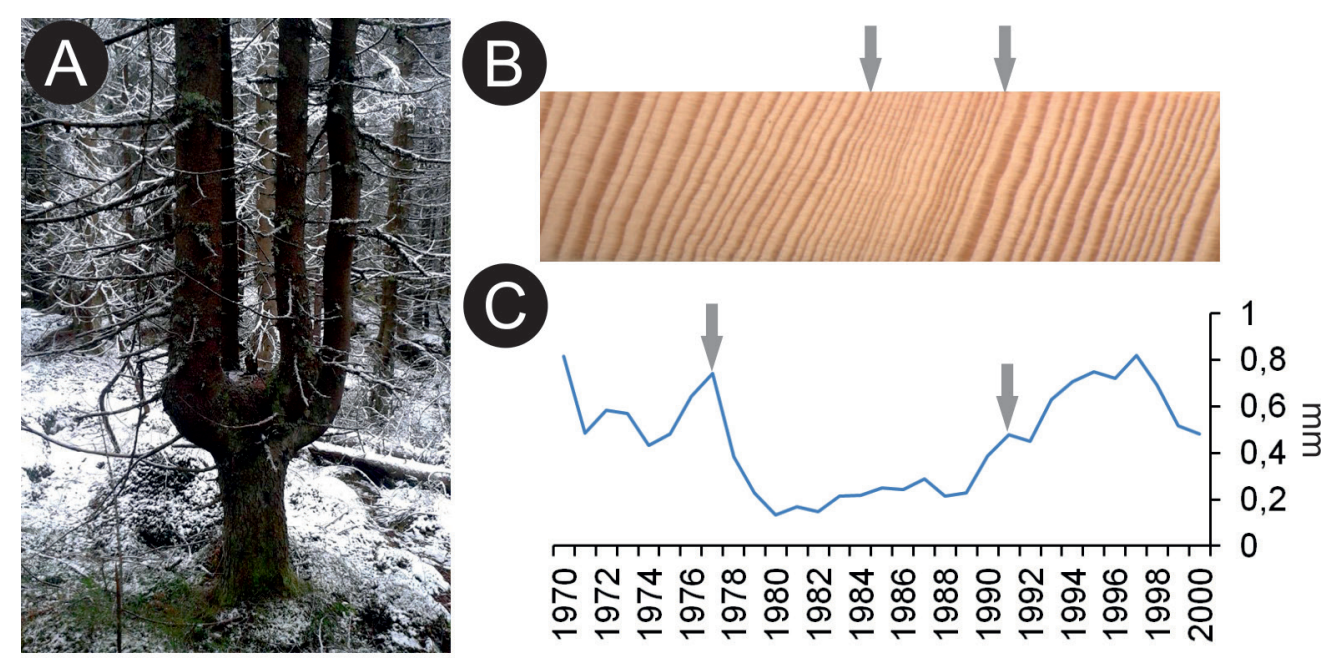

Ryc. 4. Dekapitacja drzewa (A), redukcja szerokości przyrostów wynikająca ze ścięcia wierzchołka drzewa widoczna w drewnie (B) i na dendrogramie $(\mathrm{C})$

Fig. 4. Tree decapitation (A), visible growth reduction in a tree connected with the decapitation of the top of tree (B), dendrogram for sample with tree ring growth reduction $(\mathrm{C})$ 
a ich przyrosty roczne mogą wykazywać dekoncentryczność (Timell 1986, Wistuba i in. 2013). Podobnie jak w przypadku dekapitacji, główną cechą rozpoznawczą drzew, w przyrostach których wystąpić może drewno reakcyjne, jest niesymetryczny pokrój i kształt samego pnia („fajkowato" wygięta dolna część pnia). Opróbowanie takich drzew musi uwzględniać orientację odwiertu względem nachylenia stoku.

Kolejne źródło informacji o zdarzeniach lawinowych stanowią martwe drzewa znajdujące się w obrębie lawiniska. W strefie depozycji większość rumoszu drzewnego pochodzi z drzew zniszczonych przez lawiny. Zastosowanie klasycznych technik datowania pomostowego pozwala określić czas śmierci tych drzew. Jednakże zastosowanie tego typu nośnika informacji jest niewielkie, ponieważ nawet $\mathrm{w}$ chłodnych warunkach górskich klimatu umiarkowanego, martwe drewno ulega szybkiemu rozkładowi utrudniając pobór prób i analizy. Dodatkowym ograniczeniem jest fakt, iż otrzymanie wiarygodnego metodycznie wyniku datowania wymaga odpowiedniej liczby słojów w badanym fragmencie drewna (Zielski, Krąpiec 2009).

Należy pamiętać, że wszystkie wymienione wyżej uszkodzenia drzew mogą być powodowane przez różnorakie czynniki, również te niezwiązane z lawinami. Należy brać pod uwagę szerokie spektrum takich procesów jak (Schweingruber 1996): pochylenia i zranienia drzew związane z ruchami masowymi czy spełzywaniem śniegu; uszkodzenia pni w wyniku aktywności ludzi i zwierząt; dekapitacje na skutek silnych wiatrów. Występowanie martwych drzew w obrębie lawiniska może również być efektem działania wiatru, ale także masowego pojawu kornika (Schweingruber 1996). W związku z tym, jednym z największych wyzwań rekonstrukcji dendrogeomorfologicznych jest wyselekcjonowanie sygnału, który odpowiada realnym zdarzeniom lawinowym. Sygnał ten maskowany jest przez wszystkie pojedyncze zdarzenia związane $\mathrm{z}$ funkcjonowaniem lasu górnoreglowego i wpływem człowieka na to środowisko. Już na etapie prac terenowych należy odpowiednio dobierać drzewa, które podlegają opróbowaniu. Należy rezygnować z poboru prób z drzew rosnących wzdłuż dróg i ścieżek, ponieważ ich uszkodzenia mogą powstawać w wyniku ingerencji człowieka. Ponadto nie należy uwzględniać drzew rosnących wzdłuż strumieni i potoków, gdyż geneza uszkodzeń pni może być związana z wezbraniami i intensywną erozją. Również zwierzęta przyczyniają się do powstawania uszkodzeń drzew, jednak kształt takich blizn znacznie odbiega od kształtu tych wywołanych przez lawiny. W tym przypadku godną polecenia metodą jest konsultowanie się z leśniczym nadzorującym dany teren.

\section{Badania laboratoryjne}

Pozyskane w trakcie prac terenowych próby dendrochronologiczne należy w odpowiedni sposób spreparować stosując tradycyjne metody szeroko opisywane w podręcznikach (Schweingruber 1989, 1996, Zielski, Krąpiec 2009). Pomiar szerokości przyrostów rocznych odbywa się za pomocą różnych technik (przyrostomierz stolikowy, skan itp.), gwarantujących dokładność rzędu 0,05 $\mathrm{mm}$. Starannie wyszlifowane próby pozwalają na obserwację większości zmian anatomicznych przy użyciu mikroskopów stereoskopowych.

Pierwszym etapem analiz danych dendrochronologicznych jest określnie kompletności sekwencji przyrostów rocznych w każdym badanym rdzeniu. Służy do tego datowanie pomostowe (Zielski, Krąpiec 2009), czyli porównanie badanych sekwencji przyrostów (dendrogramu) z wzorcem reprezentującym zmienność szerokości przyrostów szerszej populacji drzew danego gatunku (chronologią). Zestawienie to wykonuje się używając różnych wskaźników statystycznych oraz optycznie porównując wykresy. Zgodność przebiegu dendrogramu i chronologii pozwala przyporządkować każdemu przyrostowi rok kalendarzowy, w którym dany słój powstał. Określanie czasu powstania uszkodzeń i zmian anatomicznych nie może opierać się o proste liczenie przyrostów. W wyniku oddziaływania różnych czynników stresowych, część kambium może pozostawać nieaktywna w okresie jednego roku lub kilku lat. W wyniku tego, w sekwencji przyrostów może brakować słojów (tzw. przyrosty wyklinowujące się lub brakujące). Wzorcem jest chronologia stanowiskowa i/lub dendrogram reprezentujący nieuszkodzoną część pnia (Z). W przypadku wykorzystania próby $Z$, należy zweryfikować kompletność sekwencji przyrostów poprzez zestawienie jej z chronologią stanowiskową lub chronologią regionalną (Zielski, Krąpiec 2009). Porównanie przebiegu przyrostów rocznych prób pochodzących z badanych drzew z chronologią jest również konieczne w celu zidentyfikowaniu redukcji szerokości słojów wywołanych dekapitacją. Za takie uznać można jedynie te, które występują w próbach pobranych z uszkodzonych drzew. Współwystępowanie wąskich przyrostów w dendrogramach z tych drzew i chronologii sugeruje, że zmiany szerokości przyrostów nie są związane z uszkodzeniami, ale są wynikiem oddziaływania bardziej powszechnych czynników np. wpływu klimatu.

W datowaniach blizn nie należy wykorzystywać przyrostów pochodzących z części zarastającej uszkodzenie. Szczegółowe analizy wykazały, że otrzymana w ten sposób data może być obarczona losowym błędem od 1 roku do 75 lat (Kaczka i in. 2014).

Analiza kompletności najbardziej zewnętrznego przyrostu $\mathrm{W}$ obrębie uszkodzenia pomaga w potwierdzeniu jego związku z lawiną. Stwierdzenie w tym przyroście w pełni wykształconego drewna późnego świadczy o powstaniu uszkodzenia w okresie jesiennym, zimowym lub wczesnowiosennym. Uszkodzenia związane z lawinami powstają w części tego okresu, tj. zima - wczesna wiosna. W tym czasie kambium jest nieaktywne i nie produkuje komórek drewna, natomiast przyrost z poprzedniego sezonu wegetacyjnego jest kompletny. Założenie to pozwala zidentyfikować i odrzucić wszystkie uszkodzenia powstające w sezonie wegetacyjnym.

Błędy $\mathrm{w}$ datowaniu blizny mogą wynikać również ze stopnia zachowania drewna powstałego przed zda- 

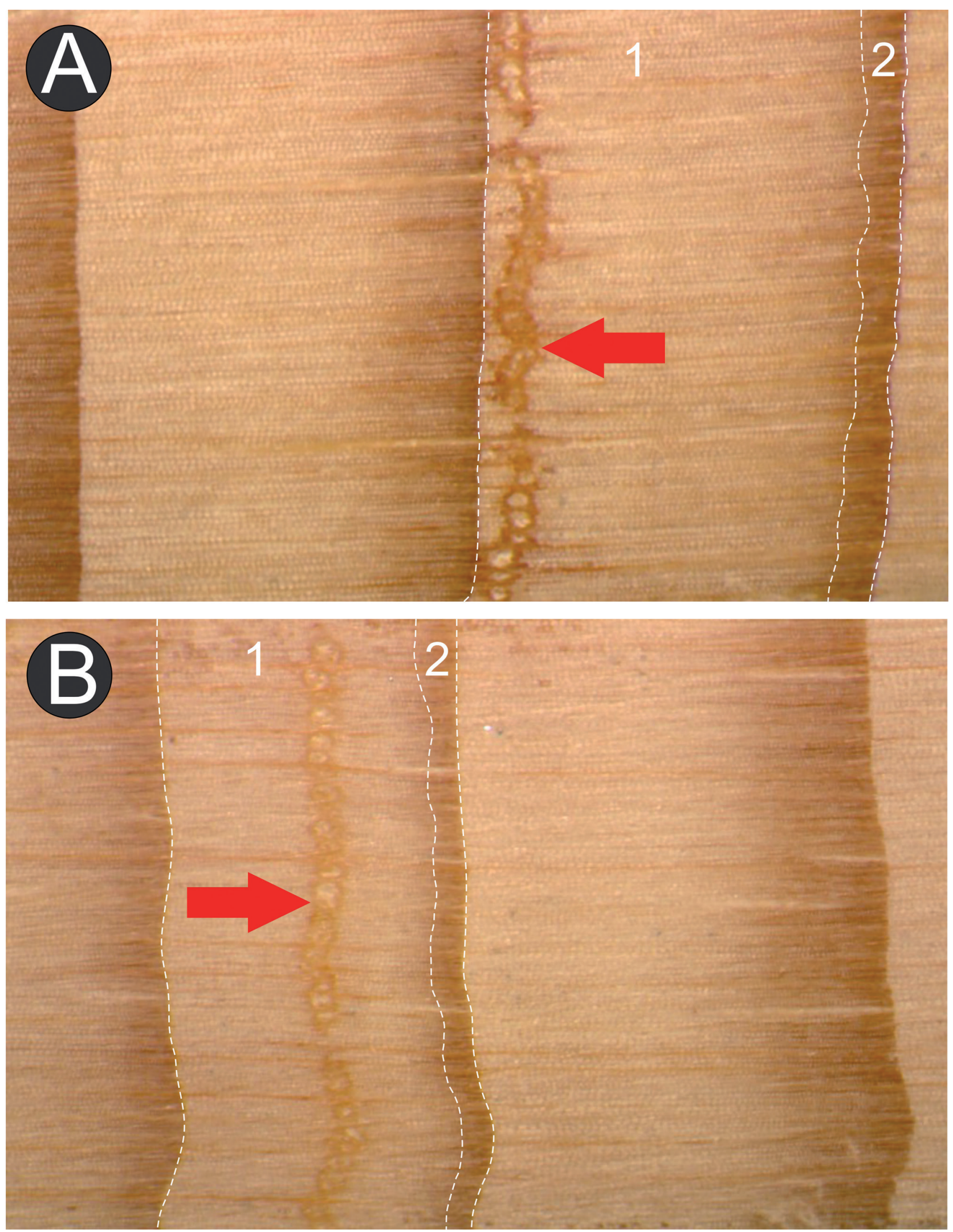

Ryc. 5. Traumatyczne kanały żywiczne (strzałka czerwona) o różnym położeniu w obrębie przyrostu rocznego świerka pospolitego 1 - drewno wczesne, 2 - drewno późne, A - w obrębie pierwszych komórek drewna wczesnego, co wskazuje na uszkodzenie drzewa w zimie lub na początku wiosny, B - w połowie drewna wczesnego, co wiąże ich powstanie z przełomem wiosny i lata

Fig. 5. The differences in the location of the traumatic resin ducts (indicated by red arrow) within the annual ring of Norway Spruce 1 - earlywood, 2 - latewood, A - development of traumatic resin ducts in the first cells of the earlywood indicates the injury during winter or early spring, B - the location of traumatic resin ducts in the later portion of earlywood indicates the injury during late spring, early summer 
rzeniem. Wyjątkowo silne uderzenie może nie tylko uszkodzić korę, łyko oraz kambium, ale również ksylem, niszcząc część przyrostów. W tym przypadku poleganie jedynie na datowaniu sekwencji przyrostów z prób pobieranych bezpośrednio z blizny (próba $\mathrm{X}$ ) może skutkować powstaniem błędów w datowaniu zdarzeń lawinowych. Prostą metodą weryfikacji dat otrzymanych $\mathrm{z}$ datowania uszkodzeń $w$ drzewach iglastych, jest stwierdzenie obecności TKZ, tj. traumatycznych kanałów żywicznych (Bollschweiler i in. 2008b) (ryc. 5). W przypadku tych drzew uszkodzenia pni uruchamiają specyficzny mechanizm obronny. Polega on na stymulowaniu odpowiednich komórek wydzielniczych i produkcji dużej ilości żywicy, która dostaje się do uszkodzonej części drzewa przewodami (kanałami) żywicznymi. W drewnie większości drzew iglastych (z wyjątkiem np. jodły) pojedyncze przewody żywiczne występują również w normalnych warunkach. W przypadku uszkodzeń mechanicznych drewna ich ilość oraz rozmiary wyraźnie rosną. Formowane są szeregi kanałów żywicznych o dużych średnicach. Obie te cechy odróżniają traumatyczne kanały żywiczne od normalnych (Bollschweiler i in. 2008b, Stoffel, Hitz 2008, Schneuwly $i$ in. 2009). Dodatkową informacją jest usytuowanie kanałów żywicznych w obrębie przyrostu rocznego. Uszkodzenia drzewa, które mają miejsce w zimie, powodują powstanie kanałów żywicznych w okresie wiosennym, wraz z rozpoczęciem okresu wegetacyjnego. Jedynie TKZ zidentyfikowane $\mathrm{w}$ pierwszych rzędach komórek drewna wczesnego mogą być wiązane ze zdarzeniami lawinowymi (ryc. 5a). TKZ występujące w połowie szerokości przyrostu związane są z uszkodzeniem pnia mającym miejsce na przełomie wiosny i lata (ryc. 5b). Zestawianie wyników datowania pomostowego blizn i analizy anatomicznej odpowiadających im TKZ, pozwala uzyskać większą pewność otrzymywanych informacji o czasie wystąpienia lawin. Pozyskany na podstawie datowania krzyżowego rok $\left(\mathrm{t}_{\mathrm{x}}\right)$ określający powstanie ostatniego, w pełni wykształconego przed uszkodzeniem przyrostu rocznego, powinien bezpośrednio poprzedzać przyrost zawierający traumatyczne kanały żywiczne $\left(\mathrm{t}_{\mathrm{x}+1}\right)$. Jeśli to założenie jest spełnione, a TKZ zostały zidentyfikowane w pierwszych komórkach drewna wczesnego, rekonstruowane zdarzenie doprowadziło do uszkodzenia drzewa $\mathrm{w}$ okresie międzywegetacyjnym (jesień roku $\mathrm{t}_{\mathrm{x}}$ - wiosna roku t $\left.t_{x+1}\right)$.

\section{Metody statystyczne w analizie dendrochronologicznej}

Przyrosty drzew stanowią archiwum, w którym zapisuje się oddziaływanie różnych czynników. Czytelność i wiarygodność sygnału związana jest $z$ odpowiednim wyborem drzew do badań oraz wielkością opróbowanej populacji. Zdarzenia lawinowe należą do istotnych pod względem siły i wielkości czynników destrukcyjnych. Przyjąć można, że na ograniczonej przestrzeni (w bezpośrednim sąsiedztwie szlaku lawinowego) i w krótkim czasie (ww. zdefiniowany okres międzywegetacyjny) dominuje ten jeden czynnik. Wystąpienie zdarzenia lawinowego może jednak zostać stwierdzone jedynie w przypadku kiedy powtarzalność informacji otrzymanych z jednego miejsca jest odpowiednio wysoka. Dla zobiektywizowania procesu ewaluacji wyników, stosowane są metody statystyczne, spośród których najpopularniejsza polega na obliczaniu wskaźnika zdarzeń (Shroder 1978, Braam i in. 1987). Jego adaptacją jest indeks aktywności lawinowej (IAL) (Decaulne i in. 2012) stanowiący procent liczby opróbowanych drzew, w których w danym roku wystąpiły uszkodzenia (Rt) w odniesieniu do liczby drzew rosnących w tym roku (At).

$$
\mathrm{IAL}=\left(\sum_{t=i}^{n} R t\right) \div\left(\sum_{t=i}^{n} A t\right) \times 100
$$

Zestawienie wartości indeksu dla kolejnych lat stanowi swoisty kalendarz aktywności lawinowej na danym obszarze (ryc. 6). W celu wyodrębnienia głównych zdarzeń lawinowych konieczne jest przyjęcie progowej wartości granicznej IAL, poniżej której zarejestrowane zdarzenia będą uważane za niepewne. W badaniach stosuje się różne wartości progowe, zależne od charakteru badanego środo-

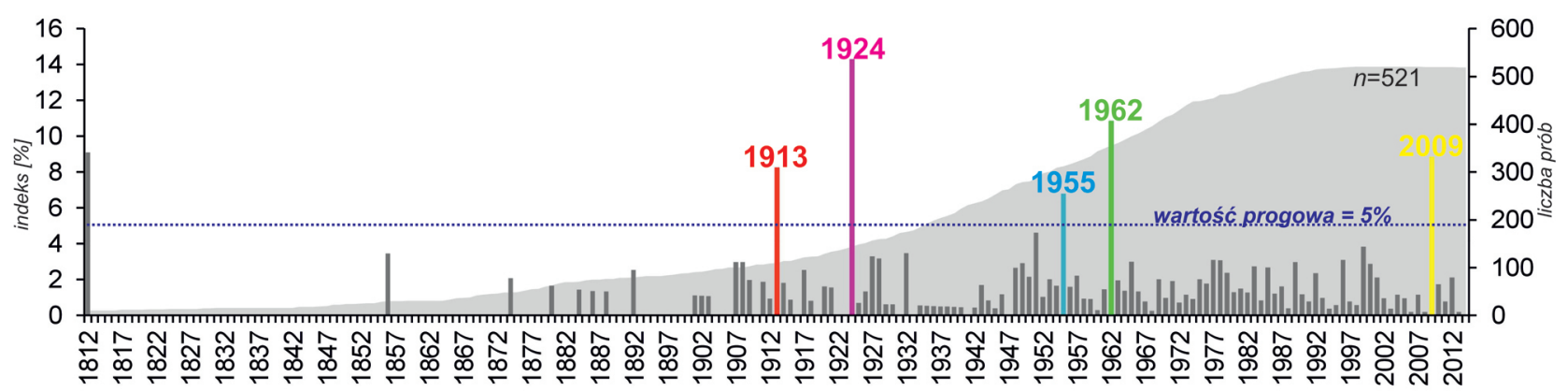

Ryc. 6. Chronologia zdarzeń lawinowych powstała w oparciu o analizę uszkodzeń drzew rosnących na granicy szlaku lawinowego w Białym Żlebie. Częstotliwość wystąpienia uszkodzeń wyrażono indeksem aktywności lawinowej. Pięć najsilniejszych sygnałów, których wartość indeksu przekracza 5\% zaznaczono kolorem (na podstawie Lempa i in. 2014)

Fig. 6. Chronology of avalanches' events based on the analyses of trees growing on the limits of the avalanche path. The incidence of damage expressed with response index. The five strongest signals, with index value higher than 5\% phrased in color (based on Lempa et al. 2014) 
wiska i zgromadzonego materiału (Dubé i in. 2004, Butler $\mathrm{i}$ in. 2010, Laska, Kaczka 2010, Lempa i in. 2014, Chiroiu i in. 2015). Główną wadą istniejącego indeksu, podobnie jak tych eksponujących współwystępowanie różnego rodzaju sygnałów dendrochronologicznych (Czajka i in. 2015), jest uzyskiwanie nierealistycznie dużych wartości dla okresu reprezentowanego przez małą ilości prób (Rt). W tej sytuacji, podobnie jak w przypadku wszystkich rekonstrukcji dendrochronologicznych konieczne jest ustalenie minimalnej replikacji prób, którą można uznać za wiarygodną. Mając na uwadze powszechnie stosowane w dendroklimatologii praktyki (Kaczka 2004, Büntgen $\mathrm{i}$ in. 2007), proponowana jest wartość $\mathrm{Rt}=5$, jako minimalna wymagana powtarzalność prób dla każdego roku rekonstrukcji (Lempa i in. 2014).

\section{Lączenie badań dendrochronologicznych $z$ analizami przestrzennymi}

Wykorzystanie dodatkowej dokumentacji zebranej w trakcie badań terenowych, pozwala dodać do wyników datowań inne cenne informacje. Oprócz precyzyjnych informacji o położeniu każdego drzewa, do pozyskiwanych danych należą wyniki pomiarów: wymiary drzewa (wysokość, pierśnica), rozmiary blizny i wysokość, na której znajduje się ona na drzewie. Zastosowanie podstawowych technik GIS i budowa prostych geobaz umożliwia opracowanie rekonstrukcji określającej nie tylko czas, ale i przestrzenny zasięg poszczególnych, zarejestrowanych w drzewach zdarzeń lawinowych (ryc. 7). Informacje te można zestawić z danymi kartograficznymi (ryc. 2) i uzyskać pełniejszy obraz zmian środowiska danego fragmentu obszaru wysokogórskiego (Lempa i in. 2014). Dodanie danych o wysokości, na której znajdują się uszkodzenia sprzed kilku, czy kilkudziesięciu lat, wzbogaca obraz re-

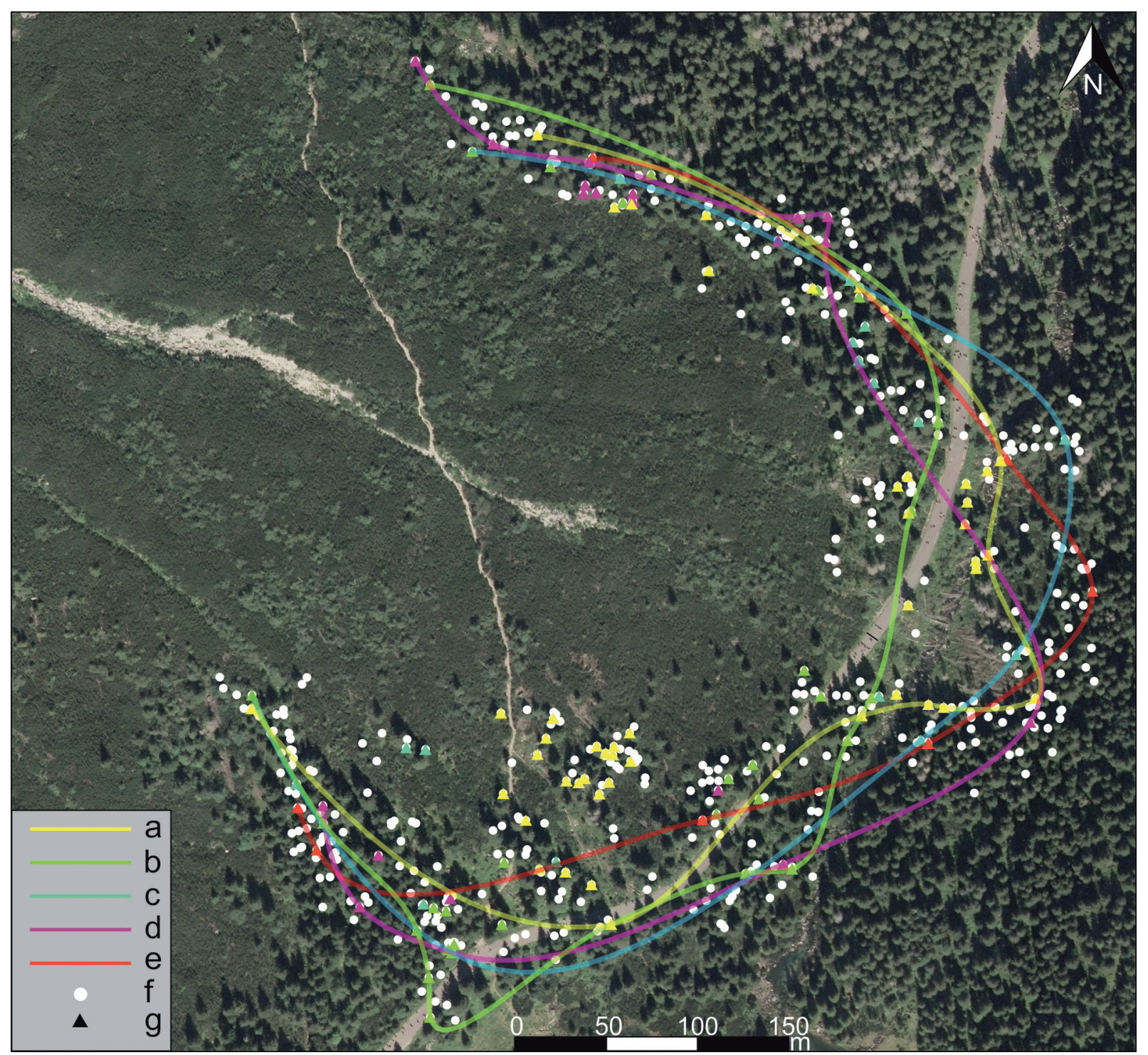

Ryc. 7. Przestrzenny zasięg zdarzeń lawinowych dla lat 2009 (a), 1962 (b), 1955(c), 1924 (d), 1913 (e), w których wartość indeksu aktywności lawinowej przekroczyła 5\%

Fig. 7. Spatial range of avalanche events for years2009 (a), 1962 (b), 1955(c), 1924 (d), 1913 (e), with the response index higher than 5\% 


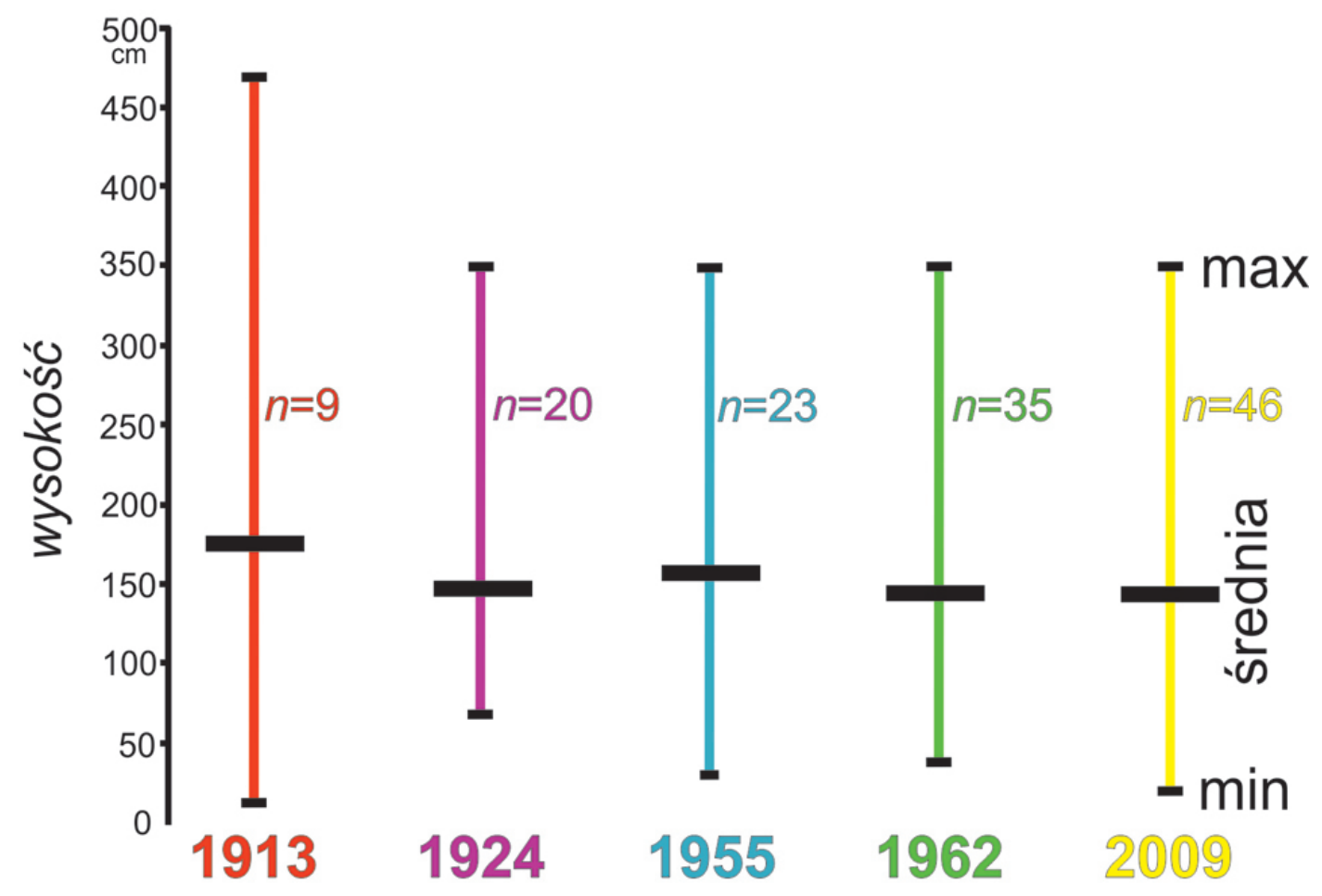

Ryc. 8. Wysokość powstałych na drzewach uszkodzeń, dla pięciu głównych, zrekonstruowanych zdarzeń lawinowych (por. ryc. 6) Fig. 8. Height of the damages occurred during the five main reconstructed avalanche events (see fig. 6)

konstrukcji o kolejny wymiar, informując o miąższości śniegu w różnych częściach lawiniska (ryc. 8) (Casteller $\mathrm{i}$ in. 2008, Kose $\mathrm{i}$ in. 2010).

\section{Podsumowanie}

Metody dendrochronologiczne znajdują uzasadnione zastosowanie w pracach, których celem jest precyzyjne określenie czasowej dynamiki zdarzeń lawinowych. Ograniczeniem w długości rekonstrukcji jest jedynie wiek drzew rosnących na granicy szlaku lawinowego i lasu.

Skuteczne wykorzystanie metod dendrochronologicznych w badaniach geomorfologicznych wymaga nie tylko znajomości technik z nią związanych, ale również szerszej wiedzy środowiskowej. Dotyczy to zarówno procesów takich jak lawiny śnieżne, ale i cech środowiska geograficznego, w jakich funkcjonuje las. $\mathrm{Z}$ tego powodu interdyscyplinarny zespół badawczy wydaje się być odpowiedni do realizacji tego typu badań.

Przedstawione podstawy metodyczne znajdują zastosowanie również w badaniach innych procesów (m. in. spływy gruzowe, obrywy skalne, wezbrania), dla których określenie dendrogeomorfologia wydaje się być bardziej odpowiednie niż w stosunku do samych lawin. Techniki dendrogeomorfologiczne nie różnią się założeniami metodycznymi od tych stosowanych w klasycznej dendrochronologii. Wymagają więc przestrzegania tych samych zasad postępowania w terenie, jak i w laboratorium.

Połączenie metod dendrochronologicznych $\mathrm{z}$ technikami GIS stwarza możliwości uzyskania dodatkowych informacji takich jak analizy czasoprzestrzennej dynamiki zdarzeń lawinowych.

\section{Podziękowania}

Badania sfinansowano $\mathrm{z}$ projektu badawczego NCN 2011/03/B/ST10/06115 Aktywność lawin śnieżnych jako wskaźnik zmian środowiska przyrodniczego $w$ okresie ostatnich 200 lat.

\section{Literatura}

Alestalo J., 1971. Dendrochronological interpretation of geomorphic processes. Fennia 105: 1-140.

Bajkiewicz-Grabowska E., Mikulski Z, 2011. Hydrologia ogólna. Wydawnictwo Naukowe PWN, Warszawa.

Becht M., 1995. Slope erosion processes in the Alps. In: O.Slaymaker (ed.), Steepland Geomorphology. Wiley, New York: 45-61.

Bollschweiler M., Stoffel M., Schneuwly D.M., 2008a. Dynamics in debris-flow activity on a forested cone - a case study using different dendroecological approaches. Catena 72: 67-78.

Bollschweiler M., Stoffel M., Schneuwly D.M., Bourqui K., 2008 b. Traumatic resin ducts in Larix deciduas steams impacted by debris flows. Tree Physiology 28: 255-263.

Braam R. R., Weiss E. E. J., Burrough P. A., 1987. Spatial and temporal analysis of mass movement using dendrochronology. Catena 14(6): 573-584.

Büntgen U., Frank D. C., Kaczka R. J., Verstege A., Zwijacz-Kozica T., Esper, J., 2007. Growth responses to climate in a multi-species tree-ring network in the Western Carpathian Tatra Mountains, Poland and Slovakia. Tree Physiology 27(5): 689-702.

Butler D.R., Malanson G.P., 1985. A history of high-magnitude snow avalanches, southern Glacier National Park, Montana, U.S.A. Mountain Research and Development 5: 175-182. 
Butler D.R., Sawyer C.F., Maas J.A, 2010. Tree-Ring Dating of Snow Avalanches in Glacier National Park, Montana, USA. In: M.Stoffel, M.Bollschweiler, D.R.Butler, B.H.Luckman (eds), Tree Rings and Natural Hazards: A state-of-the-art. Springer, Dordrecht Heidelberg London New York: 35-46.

Carrara P. E., 1979. The determination of snow avalanche frequency through tree-ring analysis and historical records at Ophir, Colorado. Geological Society of America Bulletin 90(8): 773-780.

Casteller, A., Christen, M., Villalba, R., Martínez, H., Stöckli, V., Leiva, J. C., Bartelt, P., 2008. Validating numerical simulations of snow avalanches using dendrochronology: the Cerro Ventana event in Northern Patagonia, Argentina. Natural Hazards and Earth System Science 8(3): 433-443.

Chiroiu P., Stoffel M., Onaca A., Urdea P., 2015. Testing dendrogeomorphic approaches and thresholds to reconstruct snow avalanche activity in the Făgarăş Mountains (Romanian Carpathians). Quaternary Geochronology 27: 1-10.

Chomicz K., Kłapowa M., 1969. Obserwacje lawin śnieżnych w Tatrach. Wierchy 38: 137-153.

Chomicz K., Knazovicky L., 1974. Laviny,. W: M.Koncek (red.), Klimat Tatr. VEDA, Bratislava: 581-600.

Corona C., Rovéra G., Lopez S. J. Stoffel M., Perfettini P., 2010. Spatio-temporal reconstruction of snow avalanche activity using tree rings: Pierres Jean Jeanne avalanche talus, Massif de l'Oisans, France. Catena 83(2): 107-118.

Czajka B., Kaczka R.J., Guzik M., 2012. Zmiany morfometrii szlaków lawinowych w Dolinie Kościeliskiej od utworzenia Tatrzańskiego Parku Narodowego. Prace Wydziału Nauk o Ziemi Uniwersytetu Śląskiego, Wydawnictwo Pozkal 77: 126-135.

Czajka, B., Łajczak, A., Kaczka, R. J., 2015. The dynamics of the timberline ecotone on the asymmetric ridge of the Babia Góra Massif, Western Carpathians. Geographia Polonica 88(2): 85-102.

Decaulne A., Eggertsson Ó., Sæmundsson P., 2012. A first dendrogeomorphologic approach of snow avalanche magnitude - frequency in Northern Iceland. Geomorphology 167-168: 35-44.

Decaulne A., Sæmundsson P., 2008. Dendrogeomorphology as a tool to unravel snow-avalanche activity: preliminary results from the Fnjóskadalur test site, Northern Iceland. Norsk Geografisk Tidsskrift 62(2): 55-65.

Dorren L. K., Berger F., 2006. Stem breakage of trees and energy dissipation during rockfall impacts. Tree Physiology 26: 63-71.

Douglass, A. E. 1941. Crossdating in Dendrochronology. Journal of Forestry 39(10): 825-831.

Dubé S., Filion L., Hétu B., 2004. Tree-ring reconstruction of high-magnitude snow avalanches in the northern Gaspé Peninsula. Arctic, Antarctic, and Alpine Research 36: 555-564.

Fritts H. C., 1976. Tree rings and climate. Academic Press.

Grisino-Mayer H., 2003. A manual and tutorial for the proper use of an increment borer. Tree-Ring Research 59(2): 63 -79.

Hreško J., Boltižar M., Bugár G., 2005. The present-day development of landforms and landcover in alpine environment - Tatra Mts (Slovakia). Studia Geomorphologica Carpatho-Balcanica 39: 23-48.

Jomelli V., Francou B., 2000. Comparing the characteristics of rockfall talus and snow avalanche landforms in an Alpine environment using a new methodological approach: Massif des Ecrins, French Alps. Geomorphology 35(3): 181-192.

Kaczka R. J., Czajka B., Janecka K., 2014. Ocena dokładności dendrochronologicznego datowania ekstremalnych zdarzeń geomorfologicznych. Spojrzenie w głąb słoja - anatomia drewna w badaniach dendrochronologicznych, Studia i Materiały Centrum Edukacji Przyrodniczo-Leśnej 40(3): 282-289.

Kaczka R.J., Deslauriers A., Morin H., 2010. High-precision dating of debris-flow events within the growing season. In: M.Stoffel, M.Bollschweiler, D.R.Butler, B.H.Luckman (eds), Tree Rings and Natural Hazards: A state-of-the-art. Springer, Dordrecht Heidelberg London New York: 395-401.

Kaczka R.J., Lempa M., Czajka B., Janecka K., Rączkowska Z., Hreško J., Bugar G., 2015. The recent changes of timberline in the Tatra Mountains. A case study of the Rybi Potok (Poland) and the Mengusovska Valley (Slovakia). Geographia Polonica 88(2):71-88.

Kaczka. R.J., 2004. Dendrochronologiczny zapis zmian klimatu Tatr od schyłku małej epoki lodowej (na przykładzie Doliny Gąsienicowej).
W: A.Kotarba (red.), Rola małej epoki lodowej w przekształcaniu środowiska przyrodniczego Tatr. Prace Geograficzne 197: 87-113.

Kłapa M., 1959. Lawiny. Wierchy 28: 127-163.

Kłapowa M., 1974. Szata śnieżna w Tatrach. Czasopismo Geograficzne 45: 95-111.

Kłapowa M., 1976. Mapa zagrożenia lawinowego w Tatrach. Wynik kartowania lawin snieżnych zimą 1969/1970, 8 arkuszy.

Klimaszewski M., 1981. Geomorfologia. Państwowe Wydawnictwo Naukowe, Warszawa.

Kose N., Aydın A., Akkemik U., Yurtseven H., Guner T. 2010. Using tree-ring signals and numerical model to identify the snow avalanche tracks in Kastamonu, Turkey. Natural Hazards 54 (2):435-449.

Kotarba A., Kaszowski L., Krzemień K., 1987. High-mountain denudational system of the Polish Tatra Mountains. Geographical Studies 3: $38-44$.

Kotarba A., Starkel L., 1972. Holocene morphogenetic altitudinal zones in the Carpathians. Studia Geomorphologica Carpatho-Balcanica 6: 21-35.

Laska M., Kaczka R.J., 2010. Dendrochronologiczna rekonstrukcja lawin w Tatrach Wysokich. Nauka a zarządzanie obszarem Tatr i ich otoczeniem, Zakopane 1: 89-94.

Lempa M, Kaczka R. J., Raczkowska Z., 2014. Rekonstrukcja aktywności lawin śnieżnych w Białym Żlebie w (Tatry Wysokie) na podstawie przyrostów rocznych świerka pospolitego (Picea abies L. Karst.). Spojrzenie w głąb słoja - anatomia drewna w badaniach dendrochronologicznych. Studia i Materiały Centrum Edukacji Przyrodniczo-Leśnej 40(3): 105-112.

Luckman B. H., 2010. Dendrogeomorphology and snow avalanche research. In: M.Stoffel, M.Bollschweiler, D.R.Butler, B.H.Luckman (eds), Tree Rings and Natural Hazards: A state-of-the-art. Springer, Dordrecht Heidelberg London New York: 27-34.

Luckman B.H., 1978. Geomorphic work of snow avalanches in the Canadian Rocky Mountains. Arctic and Alpine Research 10: 261-276.

Lundström T., Jonsson M. J., Volkwein A., Stoffel M., 2009. Reactions and energy absorption of trees subject to rockfall: A detailed assessment using a new experimental method. Tree Physiology 29: $345-359$.

Lundström T., Stoffel M., Stöckli V., 2008. Fresh-stem bending of silver fir and Norway spruce. Tree Physiology 28: 355-366.

Myczkowski S., 1956. Lawina a las tatrzański. Wierchy 25: 198-201.

Myczkowski S., 1962. Wpływ lawin śnieżnych na lasy Tatrzańskiego Parku Narodowego w dolinach: Rybiego Potoku, Roztoki, Waksmundzkiej i Pańszczycy. Ochrona Przyrody 28: 83-108.

Owen G., Matthews J.A., Shakesby R.A., He X., 2006. Snow-avalanche impact landforms, deposits and effects at Urdvatnet, southern Norway: implications for avalanche style and process. Geografiska Annaler. Series A. Physical Geography: 295-307.

Pelfini M., Santilli M., 2008. Frequency of debris flows and their relation with precipitation: a case study in the Central Alps, Italy. Geomorpgology 101: 721-730.

Potter N., 1969. Tree-ring dating of snow avalanche tracks and the geomorphic activity of avalanches, northern Absaroka Mountains, Wyoming. Geological Society of America Special Papers 123: 141-166.

Pressler M. R., 1866. Der forstliche Zuwachsbohrer neuester Construction. Tharandter forstliches Jahrbuch 17: $15-23$.

Rączkowska Z., Długosz M., Gądek B., Grabiec M., Kaczka R.J., Rojan E., 2015 Uwarunkownia przyrodnicze, skutki i zmiany aktywności lawin śnieżnych w Tatrach. W: A.Kotarba (red.), Przyroda Tatrzańskiego Parku Narodowego a Człowiek, Tom I Nauki o Ziemi, Wydawnictwa Tatrzańskiego Parku Narodowego, Zakopane.

Rapp A., 1960. Recent development of mountain slope in Kärkevagge and surroundings. Geografiska Annaler 17A(2-3): 71-200.

Rossi S., Deslauriers A., Anfodillo T., Carraro V., 2007. Evidence of threshold temperatures for xylogenesis in conifers at high altitudes. Oecologia 152(1): 1-12.

Rossi S., Deslauriers A., Anfodillo T., Morin H., Saracino A., Motta R., Borghetti M., 2006. Conifers in cold environments synchronize maximum growth rate of tree ring formation with day length. New Phytologist 170(2): 301-310.

Schneuwly D.M., Stoffel M., Bollschweiler M., 2009. Formation and spread of callus tissue and tangential rows of resin ducts in Larix de- 
cidua and Picea abies following rockfall impacts. Tree Physiology 29: $281-289$

Schweingruber F.H., 1989. Tree Rings. Kluwer Academic Publishers, Holland.

Schweingruber F.H., 1993. Trees and Wood in Dendrochronology. Morphological, Anatomical, and Tree-Ring Analytical Characteristics of Trees Frequently Used in Dendrochronology. Springer Series in Wood Science.Berlin/Heidelberg.

Schweingruber F.H., 1996. Tree Rings and Environment. Dendroecology. Birmensdorf, Swiss Federal Institute for Forest, Snow and Landscape Research, Berne, Stuttgart, Vienna, Haupt.

Schweizer J., Jamieson B. J., Schneebeli M., 2003. Snow avalanche formation. Reviews of Geophysics 41(4): 2-25.

Shroder J.F., 1978. Dendrogeomorphological analysis of mass movement on Table Cliffs Plateau, Utah. Quaternary Research 9: 168-185

Smoleński J., 1932. Z badań Wysokogórskiej Stacji Naukowej w Dolinie Pięciu Stawów Polskich w Tatrach. Wierchy 10: 151-156.

Stoffel M., Bollschweiler M., 2008. Tree-ring analysis in natural hazards research: an overview. Natural Hazards and Earth System Sciences 8(2): 187-202.

Stoffel M., Bollschweiler M., Butler D. R., Luckman B. H., 2010. Tree Rings and Natural Hazards. Springer Netherlands, Dordrecht: 10-11.

Stoffel M., Bollschweiler M., Hassler G.R., 2006. Differentiating past events on a cone influenced by debris-flow and snow avalanche activity - a dendrogeomorphological approach. Earth Surface Processes and Landforms 31(11): 1424-1437.
Stoffel M., Butler D.R., Corona C., 2013. Mass movements and tree rings: a guide to dendrogeomorphic field sampling and dating. Geomorphology 200: 106-120.

Stoffel M., Corona C., 2014. Dendroecological dating of geomorphic disturbance in trees. Tree-Ring Research 70(1): 3-20.

Stoffel M., Hitz O.M., 2008. Snow avalanche and rockfall impacts leave different anatomical signatures in tree rings of Larix decidua. Tree Physiology 28: 1713-1720.

Stoffel M., Lievre I., Monbaron M., Perret S., 2005. Seasonal timing of rockfall activity on a forested slope at Taschgufer (Swiss Alps) A dendrochronological approach. Geomorphology 49: 89-106.

Timell T.E., 1986. Compression Wood in Gymnosperms. Springer-Verlag, Berlin.

TPN [Tatrzański Park Narodowy], 1999-2013. Statystka. Online: tpn.pl/ zwiedzaj/turystyka/statystyka - 13.12.2014

Wistuba M., Malik I., Gärtner H., Kojs P., Owczarek P., 2013. Application of eccentric growth of tree-rings as a tool for landslide analyses (an example of Picea abies Karst. in the Carpathian and Sudeten Mountains - Central Europe). Catena 111: 41-55.

Zaruski M., 1910. Jeden dzień przy Morskim Oku. Pamiętniki Towarzystwa Tatrzańskiego, Kraków: 31-35.

Zaruski M., 1911. Lawiny śnieżne w Dolinie Rybiego Potoku w dniach 27, 28 i 29 stycznia 1911 roku. Pamiętniki Towarzystwa Tatrzańskiego, Kraków: 107-112.

Zielski A., Krąpiec M. 2009. Dendrochronologia. Państwowe Wydawnictwo Naukowe, Warszawa. 